\title{
Harnessing Internet finance with innovative cyber credit management
}

\author{
Zhangxi Lin ${ }^{1,2^{*}}$, Andrew B. Whinston ${ }^{3}$ and Shaokun Fan ${ }^{4}$
}

\author{
* Correspondence: \\ zhangxi.lin@ttu.edu \\ ${ }^{1}$ The Rawls College of Business \\ Administration, Texas Tech \\ University, 703 Flint Avenue, \\ Lubbock, TX 79409-2101, USA \\ ${ }^{2}$ Southwestern University of Finance \\ and Economics, Chengdu, Sichuan, \\ China \\ Full list of author information is \\ available at the end of the article
}

\begin{abstract}
In the last two decades, Internet technologies, such as cloud computing, mobile communications, social media, and big data analytics, have brought tremendous changes to our society and reshaped the business in various industries. Specifically, the mushrooming innovations in the financial area fertilized by information and communication technologies indicates the advent of the Internet finance era. Applying the exploratory research approach, we investigate major innovative Internet-based financial services and classify them into five categories, as of e-commerce, e-payment, e-money market, online loan services, and digital currencies. Then we propose a market structure of Internet finance extended from the traditional financial market. We claim that credit management is the key issue in the marketplace of Internet finance, characterized by big data analytics, in which cyber credit appears as whole-process, multi-dimensional, and holographic. We further suggest that cyber credit be represented in the form of vector to overcome the limits of traditional single-value measure in cyber credit management. Based on this framework, we raise main research issues in Internet finance from the perspectives of theory, technology, and governance.

Keywords: Electronic commerce; Internet finance; Credit risk; Regulation; Financial market; Innovation
\end{abstract}

\section{Background}

In 1993, "Making money on the Internet" inspired the global gold rush in electronic commerce (e-commerce) along the newly opened information speedway (Glossbrenner \& Glossbrenner 1994). In a little bit more than two decades, we have experienced the tremendous changes in our society brought up by the Internet, mobile communications, electronic commerce, and, nowadays, financial innovations. We have witnessed how Google, eBay, FaceBook, Twitter, LinkedIn, Alibaba, Tencent, Microsoft, CISCO, and many others, are booming in a short period, how social networks reinforced by ubiquitous mobile communications are penetrating and occupying in our daily life, and how explosive big data in the cyber space challenges our information and communication technologies (ICT), and hence stimulates the development of newer technologies, such as Hadoop (http://www.cloudera.com/content/cloudera/en/ about/hadoop-and-big-data.html), Spark (https://spark.apache.org/), NoSQL (http:// www.mongodb.com/nosql-explained), H2O (http://0xdata.com/), etc. Electronic commerce has quickly evolved from trading of physical goods to digital goods, from primitive electronic payment to advanced financial services, and now credit based 
businesses (Niranjanamurthy \& Kavyashree 2013). Today, baby-boomers is retiring, and Generation $\mathrm{X}, \mathrm{Y}$, and $\mathrm{Z}$ are giving the way to an even newer generation dwelling deeply in the cyber world. It is the right time to claim "Making money on the Internet by credit", as the financial innovation, relying heavily on credit management, is leading the new gold rush on the information highway.

Internet finance, enabled by ICT, is evolved from electronic commerce. The concept of Internet finance can be traced back to the earlier concept of electronic finance (e-finance) or network finance, which has been defined in MBALib (http://wiki.mbalib.com/wiki/ \%Е4\%BA\%92\%E8\%81\%94\%E7\%BD\%91\%E9\%87\%91\%E8\%9E\%8D) as "the network technology and finance combined with each other", but not yet in Wikipedia. By consolidating the information from different sources, Internet finance covers many latest innovative financial services, underpinned by the Internet technologies, mobile communications, and information intermediary based on revolutionary business models (Kauffman \& Riggins 2012). Since all these innovations are rooted in the new generation of e-commerce, we can deal Internet finance as the latest evolution of ecommerce with the core in cyber-based credit management system.

This paper is intended to investigate current status of Internet finance and identify the emerging research issues in this new arena. We specifically refer more cases in China than other countries because China has been leading the development of Internet finance since 2010s. In Sections 2 and 3, after reviewing the mushrooming Internet finance businesses, we will propose a market structure of Internet finance extended from traditional financial market, raise the issue of online credit management system, and conceive an architecture of big data based credit risk management system. We argue that advanced financial services, such as p2p lending, rely on efficient and reliable credit management. We further claim that the innovative credit management with big data analysis is the key to harnessing Internet finance. Based on this framework, in Section 4 we discuss the emerging research issues in the aspects of Internet finance governance, theoretic research topics, and technological challenges, particularly regarding the big data based credit system in the Internet finance era. Section 5 presents concluding remarks for this paper.

\section{Internet finance}

\section{An overview}

With the rapid development of information technologies, specifically, cloud computing, mobile communications, and ubiquitous online social networks, IT-enabled financial innovations are penetrating almost every sector of finance. Today, businesses of Internet finance cover not only e-payment and e-banking that promoted previously brick-and-mortar financial businesses to click-click regime, but also credit, guarantee, assurance, pledge, collateralization, and so on, which are considered as more advanced financial services (Chang \& Deng 2014). At the very beginning, the applications of ICT in the finance area are merely replicates of offline financial services in the electronic form. With the synergy of e-commerce and financial industry, Internet finance has gradually formed distinctive online financial services and in turn reinforces e-commerce innovation (e.g. online to offline model). In Fig. 1, we summarize finance innovations into five categories of relevant online financial businesses. On top of the ICT and big data infrastructure, various applications have 


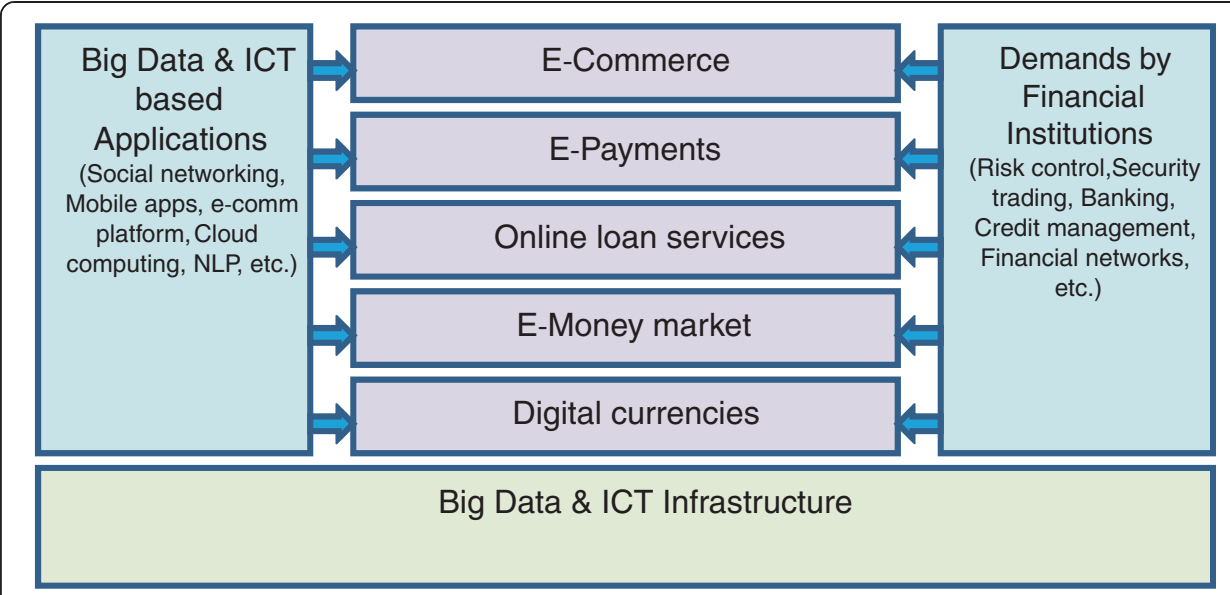

Fig. 1 Financial innovations in the Internet era

been developed to facilitated Internet finance. For example, social media are now attracting tremendous amount of attentions, and many people are heavily engaged in different social media platforms. Such social media engagements create online communities that link people from different places, and enable financial innovations within or across online communities. From the aspect of financial institutions, the Internet economy has introduced severe competitions to the financial industry. Financial institutions are facing competitions not only from their local peers, but also from rivals all over the world in different business areas, some of which may not be even considered as a financial institution in the traditional financial market. Thus, financial institutions have the strongest motivation to innovate their businesses by adopting advanced ICT (Diniz et al. 2012). The confluence of ICT and big data infrastructure, applications, and demands from financial institutions have created many innovative financial services so far. We will explore the five categories with examples in the following sections, but not the online securities trading because this kind of innovations covers too much information and beyond this paper's scope.

Innovative financial services

\section{Electronic commerce}

Electronic commerce (e-commerce) is conceptually nothing new since it has been in operation for more than 20 years. Beyond its commonly defined coverage as of the electronic businesses that trade products or services using computer networks, such as the Internet, the latest businesses in e-commerce can be identified in three aspects: online financial services, new forms of e-businesses (P2P, O2O, P2G, P2B, C2B2C, MyStore, social commerce, etc.) (Mao et al. 2015), and real-time targeted marketing (Ding et al. 2015).

Online financial services could be considered as a special kind of e-commerce selling financial services and products online, based on its fundamental form of electronic payments. Many latest e-commerce business models are actually the applications of advanced financial services in a more sophisticated structure. For example, Didi Dache and Kuaidi Dache, two of China's leading taxi-hailing applications, are based on the 
channel between the traditional banking system and the mobile payment services (Dong et al. 2014). Even real-time bidding (RTB), the latest generation of online targeted marketing, has the key ingredients from Internet finance, such as the e-billing mechanism and the programmed real-time bidding system, which is a mimic of algorithmic trading as used in the stock market (Wang \& Yuan 2015). In whatever situation, today's e-commerce always comes with various types of online financial services, and its evolutions are fundamentally financial innovations. Therefore, the follow-up subsections are to present these cornerstones in the new generation of e-commerce.

\section{Electronic payments}

Electronic payment services, including electronic banking, online financial escrow services, and other the online payment services by trusted third-party, have been the top critical success factor in e-commerce for two decades, and are the fundamental portion in Internet finance (Qiu 2013). China should be the country in the world that has been experiencing tremendous impacts from e-payment. In 2014 Chinese online payment companies grew $143.8 \%$ to 10.3 trillion yuan (\$1.66 trillion) (Tong, $F$ 2015). This growth rate is two folded from the growth rate of banking card transactions in the same period (Duncan Hewitt 2015). In a long list of successful e-payment companies, such as PayPal, PaySomple, 2C2P, Alipay, Unionpay, Tenpay, M-Pesa, DigiCash, GoCardless, etc., Alipay, born on December 30, 2004, is the most active and innovative one with its series of eye-attracting financial services launched in recent years (Qiu 2013). By a series of e-payment services since 2012, such as Quick Pay, barcode payment, and KongFu payment, Alipay facilitates customers with multiple bank accounts to simplify payment or transfer in the unique Alipay portal, and provides an online escrow service to reduce the risk perceptions of buyers and sellers in the emarket.

Alipay had been its maintaining its dominating advantages in the e-payment market, until August 5, 2013, when Tencent launched a mobile payment system on its social networking platform WeChat and quickly formed the major threat to Alipay's business territory. WeChat, an instant messaging application developed by Tencent, owns the largest user population in the world. By August 2014, WeChat had 438 million active users (http://www.tencent.com/en-us/ir/news/2015.shtml). WeChat payment quickly got popular in China, and fundamentally changed the market ecology. Application examples of WeChat payment include: $\mathrm{O} 2 \mathrm{O}$ support services, micro-merchant/microstore, e-cash envelope, etc.

December 12, 2014 is a remarkable day in China's e-payment history when Alipay's offline payment services became available, indicating that Alipay has stepped into the traditional business territory dominated by Unionpay in China. Unionpay is so far the only payment network authorized to handle yuan-denominated card transactions in China. It issued 400 bank cards in China and handled $\$ 5.3$ trillion worth of transactions in 2013. However, Alipay Wallet, a mobile app that lets consumers pay with their mobile phones in bricks-and-mortar stores, involved 190 million active users with daily transactions topped 45 million in October, 2014 (Tong, F 2015). Backed by 25 billion yuan profit and $\$ 5$ billion reserved fund of Alibaba, Alipay is more competent than Unionpay in the competition with VISA, or MasterCard, in the international market, as Unionpay's profit is less than $10 \%$ of Alibaba's profit. 


\section{Online loan services}

Currently most popular online loan services include online B2C loan, online peer-topeer (P2P) lending, and online crowdfunding. An online B2C loan service is provided by a financial company to multiple small companies or individuals via web based services and credit assessment system mainly based on customers' online financial or business transactions; Online P2P lending is the financial service provided on a platform between individual lenders and borrowers, which is actually a kind of debt financing; Crowdfunding is actually equity financing driven by the projects advertised online.

Online B2C loan services The most famous successful story of online B2C loan services is Alifinance, and now is a part of Ant Financial, founded in late 2014. AliFinance provided loans to SMEs online since 2010. By 2014 the amount of loan has totaled more than 150 billion yuan, benefiting more than one million small and medium-sized enterprises (SMEs). A SME in its service only needs a few minutes to finish the loan application, and the average processing cost is as low as 2.30 yuan, thinking about 2,000 yuan for handling a traditional business loan (Cai, K 2013). Based on its credit assessment system, Alifinance's loan service has a default rate less than $0.5 \%$ and loan life cycle is $4-$ 5 days. In July 2014, Alipay teamed up with seven banks, e.g., Bank of China, China Merchants Bank, China Construction Bank, Ping An Bank, Postal Savings Bank of China, Bank of Shanghai and Industrial Bank, to jointly offer loans of up to 10 million yuan to SMEs in China. This is the first time traditional banks offer unsecured loans to SMEs based on big data and credit system accumulated through Alibaba's online platform.

Online P2P lending Perhaps online P2P lending is the most attractive Internet finance business to many people. Online P2P lending is a new form of e-commerce in lending/ borrowing money between unrelated individuals, without going through a traditional financial intermediary such as a bank. Inaugurated in 2005, online P2P lending is getting more and more popular now (Table 1).

Table 1 Samples of P2P Lending companies in the world (Chen et al. 2014)

\begin{tabular}{|c|c|c|c|c|c|}
\hline Region & Intermediary & Start year & Region & Intermediary & Start year \\
\hline \multirow[t]{6}{*}{ US } & Prosper & 2006 & China & Yixin & 2006 \\
\hline & Zopa, LendingClub, VirginMoneyus, & 2007 & & PPDai, Qifang. & 2007 \\
\hline & Loanio, Mircroplace, Fynanz & & & Wokai & \\
\hline & People Capital. Zimple Money & 2008 & & My089 & 2009 \\
\hline & Zidisha & 2009 & & ChangDai & 2010 \\
\hline & Vittana & 2010 & France & Baby Loan & 2009 \\
\hline \multirow[t]{2}{*}{ Multi-national } & Kiva & 2005 & UK & Zopa & 2005 \\
\hline & Microplace & 2007 & & FundingCircle & 2010 \\
\hline \multirow[t]{2}{*}{ Italy } & Zopa & 2007 & Canada & IOUCentral & 2008 \\
\hline & Boober & 2007 & & CommunityLend & 2008 \\
\hline \multirow[t]{2}{*}{ Poland } & Kokos & 2008 & Japan & Zopa & 2008 \\
\hline & Monetto & 2008 & Denmark & Fairrates & 2007 \\
\hline Australia & IGrin & 2007 & Holland & Boober & 2007 \\
\hline Sweden & Loanland & 2007 & Africa & MyC4 & 2006 \\
\hline Germany & Smava & 2007 & & & \\
\hline
\end{tabular}


Online P2P lending in different regulatory systems has different implications, opportunities, and risks (Luo 2013). In well-regulated countries, such as the US, online P2P lending business is growing steadily. For example, Lending Club, one of leading online P2P companies in the US, becomes the 18th-largest IPO out of more than 264 in the U.S. when IPO was done on December 11, 2014 (Somervill, H 2014). In financially less-regulated countries, such as China, situations are quite different. In last three years, the online P2P lending market in China has experienced tremendous growth, but full of various risks. In July 2013, there were about 7,000 P2P lending companies with 700 billion yuan of loans. Among these companies about $10 \%$ were online. In April 2014 about 120 online P2P lending platforms were closed. In March 2015, the total amount of P2P loan in China is about 150 billion yuan by 1,728 P2P platforms; the default rate is close to $10 \%$, i.e. 15 billion yuan.

Crowfunding Crowdfunding, one of most successful business model of online equity financing, provides an online platform for equity financing (Luo 2013; Ordanini et al. 2011). There are various types of crowdfunding, such as rewards-based, and debt-based. As the primary type of crowdfunding, equity crowdfunding is to collect capitals from supporters to fund a project initiated by a sponsor by providing equity (Ordanini et al. 2011; Prive 2012). Today the growth of crowdfunding is getting momentum. By the end of 2013 , the worldwide crowdfunding industry grew to be over $\$ 5.1$ billion (Harrison 2013). There are two most well-known crowdfunding cases:

- Kickstarter, founded in April 2009, is the world's largest funding platform for creative projects (Kuppuswamy \& Bayus 2013). As of October 10th, 2012, 73,620 crowfunding projects were released by this website (3426 projects were in progress) (www.Sjordanassociates.com); and the success rate of financing and total funds were $43.85 \%$ and $\$ 381$ million, respectively.

- DemoHour, founded in May 2011 and also known as "the Kickstarter in China", is a crowfunding website with Chinese characteristics (Wu et al. 2015). In 2013, it has received more than 7,000 project proposals in its two years of existence, and the funded rate of projects was closer to $50 \%$.

\section{Online money market fund services}

Money market funds, with a higher yield than the bank deposits, have long been lucrative for shareholders and fund firms, but the Internet-based money market fund management is just new with distinguishing features. PayPal became the pioneer of Internet-based money market in 1999, with the average interest rate of $5 \%$, which was higher than the US market interest rate. Since the financial crisis in 2008, the yields of the fund have dropped dramatically. At the time of its closing on July 29, 2011, PayPal provides only an interest rate of $0.04 \%$ to its remaining $\$ 471$ million fund (Marte, J 2011).

In June 2012, Alipay launched its product of Yu'e Bao ("leftover treasure"), offering an annualized dividend rate up to $7 \%$. Sooner after, Tencent and Baidu also initiated similar online funds, furnishing annual interest rates of 6-10\%. The size of those online money market funds is also gigantic. As of 31 Dec 2014 (Cecilia 2015), Yu'e Bao 
made from more than 149 million users, an eye-popping RMB578.9 billion (US $\$ 94.09$ billion) assets under management (AUM), which is about $40 \%$ of the total money market fund size in China. Yu'e Bao has been recognized as the China's largest and the world's fourth largest money market fund (Johnson, E 2014).

However, the authorities of China have erected concerns, in either the interest rate liberalization which has taken a decade to play out in the US, and the fund liquidity risk due to the reason that those online money market funds offer investors the ability to withdraw money whenever they like. Banks initiated the moves immediately after the skyrocketing of online money market fund, by limiting transfers out from the bank deposit accounts to 50,000 yuan $(\$ 8,000)$ per month, so as to slow down the process as well as lesson the market risks. In April 2014, People's Bank of China issued the draft of Online Payment Operations Rules in Online Third Party Payment Platforms, aiming to protect consumer privacy, establish online payment limits based on user's financial condition, and identity verification for online transfers.

\section{Digital currencies}

Digital currencies are another kind of e-payment service but have significant impact on financial industry and on financial theories (Wagner, A 2014). Digital currency or digital money is regarded as an Internet based medium of exchange (i.e., distinct from physical, such as banknotes and coins) that possesses the properties similar to traditional currencies, with the features of Internet based services-instantaneous transactions and borderless transfer-of-ownership.

There are two kinds of digital currencies: virtual currency, and cryptocurrency (Brezo \& GBringas 2012). In 2013 The US Department of Treasury in 2013 defined virtual currency as "a medium of exchange that operates like a currency in some environments, but does not have all the attributes of real currency". The famous ones are Linden Dollar used in Second Life, and QQ coin by Tencent. Cryptocurrency, such as BitCoin, is another kind of digital currency in the form of digital series that relies on cryptography for chaining together digital signatures of token transfers, peer-to-peer networking and decentralization. In some cases a proof-of-work scheme is used to create and manage the currency. Another example of cryptocurrency is Ripple payment system, which is in fact an implementation of a payment protocol for currency exchange and remittance. With XRP, a distributed open source Internet protocol, the Ripple network purports to enable "secure, instant and nearly free global financial transactions of any size with no chargebacks".

In 2007, QQ coin has incurred a dispute in its legality and risk in the monetary system in China. In 2013 BitCoin stimulated a gold rush in mining and speculating this new currency. The problems that have been warmly discussed in many online communities include:

1) Could digital currencies be sued to replace or partially replace regular currencies in circulation?

2) How to control the risk of digital currencies mainly caused by anarchist speculators?

3) How to value digital currencies in the market? 


\section{Trends of Internet finance}

The above financial innovations characterize Internet finance as microfinance oriented, big data based, and multidiscipline-interfused. The idea of microfinance can be traced back to 15th century when the Franciscan monks founded the community-oriented pawnshops. It was promoted by the intention to make low-income individuals capable of lifting themselves out of poverty by the access to financial services. In Internet finance, microcredit, micropayment, and microloan form the family of microfinance, owing to the power of ICT. For example, Kiva, a pioneer in online P2P lending, defined microfinance as the financial services to low-income individuals or to those who do not have access to typical banking services, in which the amount of financial is relatively small. Similar to the long-tail phenomenon in e-commerce, the advent of microfinance is empowered by the advancement of ITC. When a financial transaction is split into many much smaller ones, each demanding the same level of service and generating the same amount of information. With powerful computing capacity and the decreasing cost in financing, microfinance is penetrating into various fields, delivering services to tiny financial transactions with the affordable cost. This also implies Internet finance must be capable of handling big data, and hence can be called big data finance.

Pan-finance (Sina Finance 2015) is a latest buzzword in Internet finance area, owing to the trend of multidisciplinary interfusions between finance and diversified e-commerce businesses. With the deeper penetration of ICT technologies, this trend appears to be more salient. In the Pan-finance realm, "cats and dogs are all opening banks", driven by the populace's demands of convenience, and facilitated by the technological capabilities (Shao, H 2013). For instance, M-PESA,providing mobile banking services in Africa, was launched in 2007 by the largest mobile-network operator at Kenya-Safaricom. By availing its customers to use their non-smart phones to pay bills, or transfer funds to both MPESA users and non-users, M-PESA has attracted over two-thirds of the adult population (12.2 million) in Kenya, 81,000 agent outlets, and processed around $25 \%$ of the country's gross national product flows. In the case of China, the market is even severely competitive, with the call of the central bank in July 2013 to "experiment letting private capital initiate and set up banks at their own risks". Suning Commerce, the largest retailers of home appliances in China, takes the lead by registering "Suning Bank". Alibaba received the regulatory approval though late in September 2014, also set up a private bank, named MYbank, to target in small banking businesses, with a sum of deposit no more than 200,000 yuan $(\$ 32,520)$ and a loan worth no more than 5 million yuan (Xinhua 2014). The other contenders are from the varied industries with diversified business backgrounds, i.e., electric appliances manufacturers (Gree Electronics and Midea Electronics), and agribusiness company named New Hope (Shao, H 2013). The approval of the private banks marks the Chinese government's latest efforts to deepen financial reform and support the country's small and micro-businesses.

\section{Credit services for internet finance}

It took the human society a few thousand years to evolve from the barter economy to the credit based economy, while it only took less than three decades for Internet finance from primitive e-commerce transactions to credit-product based electronic transactions. Although traditional credit management system has been working well for many years, it becomes less and less capable of coping with the challenges from 
Internet finance, as characterized by the volume, velocity, variety, and variety of the information for credit assessment and management. These features are actually the characteristics of big data.

Currently, it has been a consensus among businesses in Internet finance that online credit management is the core of financial services, as online credit management systems are getting popular worldwide. On January 5, 2015, People's Bank of China approved the first eight credit service companies in China (Li, X 2015) (Also see http:// column.iresearch.cn/u/dongyizhilvshi/695232.shtml). Among them, the Alibaba owned Sesame Credit Management Group offers a credit-scoring business to assess the customer's creditworthiness based on the online shopping preferences, repayment ability, personal information and online social networking activity (Li, X 2015). Sesame Credit collects data from 300 million individual users and 37 million small businesses on Alibaba platforms, including business-to-business portal Alibaba.com, and consumer marketplaces Taobao and Tmall (Tham, E \& Carsten 2015).

\section{Research framework}

\section{Financial market in the Internet time}

Traditionally, financial markets function as an economic platform for moving funds among households, firms, and governments, from surpluses to deficits (Mishikin, F.S 2012). There are two kinds of submarkets, direct finance and indirect finance based on financial intermediaries (Fig. 2). In a direct finance market, funds are transferred directly from lenders to borrowers via securities, or financial instruments, such as stocks, futures, ETFs, bonds, mutual funds, etc. A financial intermediary, typically a bank, plays an important role in helping transfer funds between surplus and deficits. The functions of a financial intermediary are mainly in two aspects, collecting funds and controlling risks in lending, the latter being mainly in credit risk management.

Clearly, intermediation is important in financial markets. It is the good reason that financial intermediaries conduct their business. However, the cost is high-in 2013, the

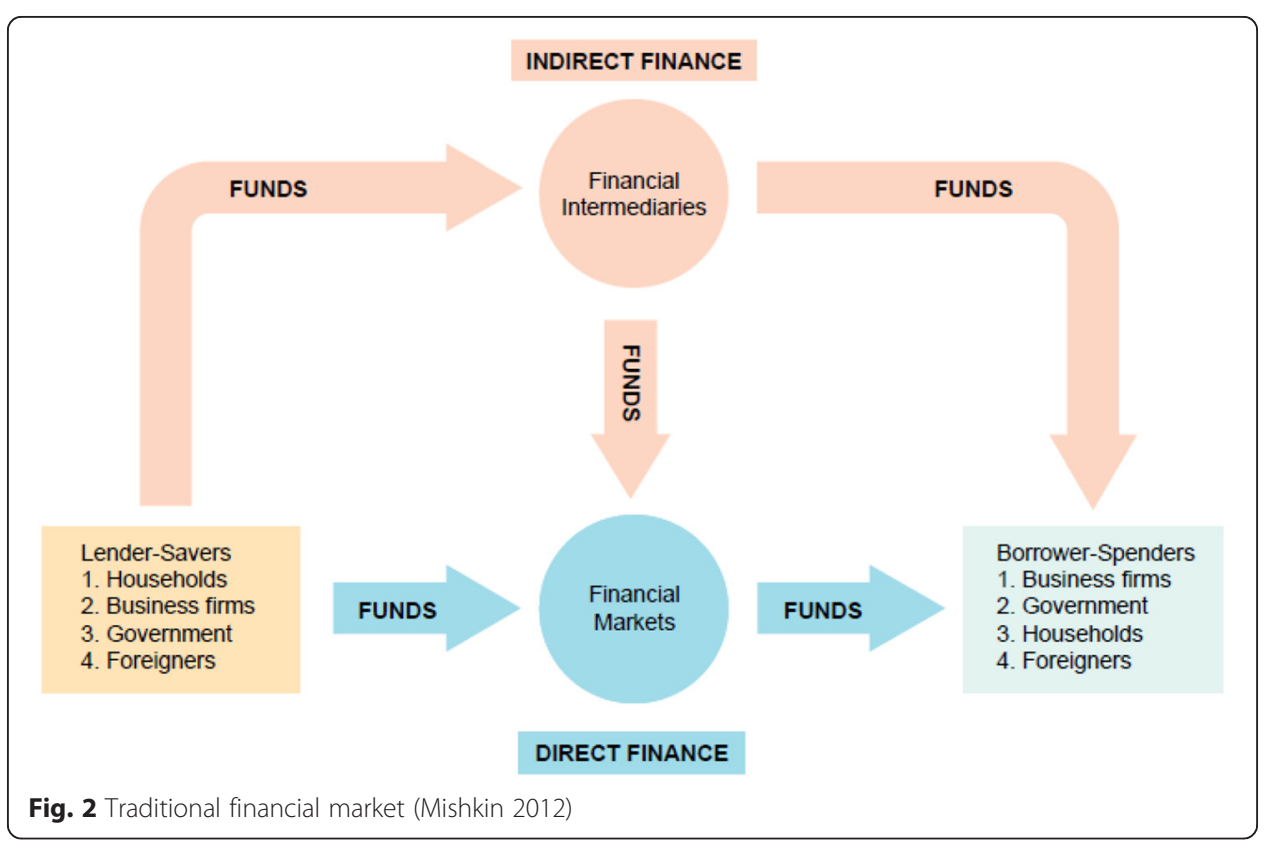


total revenue of China's commercial banks was 2.28 trillion yuan (Deloitte 2014), which is mainly from the difference of interests between saving and financing. To improve market efficiency, the society has been calling for financial disintermediation for years. Disintermediation is a process allowing a consumer to directly access to a product, service, or information without a mediator as usual but by the means of the Internet. Internet finance in nature takes the advantage of disintermediation to reduce the transaction costs and compete with traditional indirect finance effectively.

We consider an extended financial market with the involvement of e-commerce as the main portion. In Fig. 3, funds are transferred between e-commerce market and traditional financial market. There is no explicit boundary between these two, because we can always consider the online financial services, such as security trading and P2P lending, as a kind of e-commerce but the merchandises are monetary goods.

In an Internet finance market traditional intermediation services have been weakened, owning to various innovations and technologies in reducing information asymmetry. Still, credit risk management is the critical issue in the market. In more than two decades study in e-commerce, the fundamental theory applied is the adverse selection theory with the story of lemon goods initiated by Akerlof (Akerlof 1970). The new electronic environment of business makes the risk more prevailing and fast spreading. When an online agent could play any combination of four different roles in the Internet finance market, such as buyer, seller, borrower, and/or lender, the credit assessment and credit risk control become much more difficult than ever before.

\section{Cyber credit}

Credit, originated from Latin word credere as translated "to believe", is referred to as the trust which allows one party to provide resources to another party where that second party does not reimburse the first party immediately (i.e. a debt), but instead arranges either to repay or return those resources (or other materials of equal value) at a later date. There are two main types of credit management systems in the business

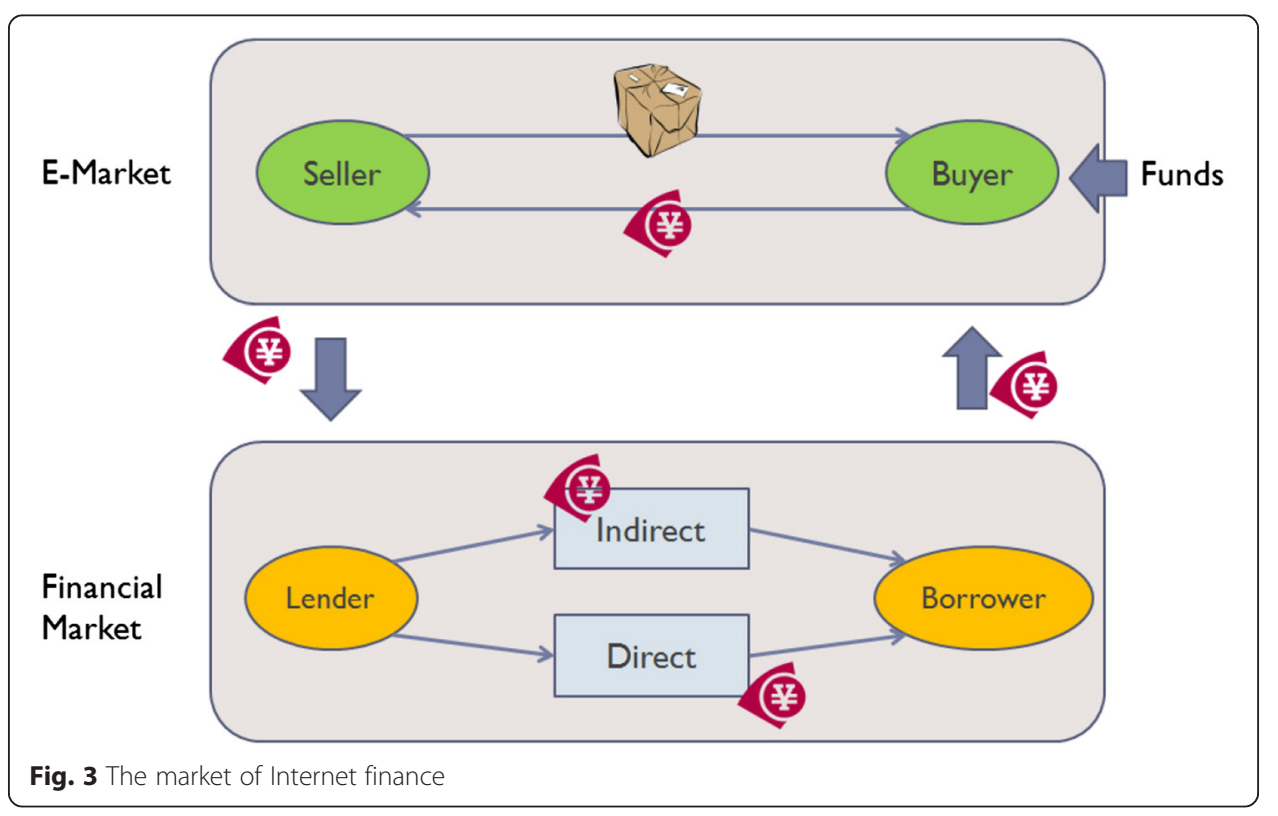


world. One is those private credit information exchanges or cooperatives, mainly involving banks, non-banking financial institutions, credit unions, and retailers, which share borrowers' credit data via the credit management agency. The credit management agency also collects public credit records to enrich the credit information. The other one is in the form of public credit registration requested by the government, via regulations applied to all financial and non-financial institutions. Legislations are requested to assure the authentication of the reported data. In the US business credit market, Dun \& Bradstreet is taking the lead, which analyzes the capacity, history, law suit cases, and financial information of a business to create credit reports. For personal credit assessment, three credit reporting agencies, Equifax, Experian, and TransUnion dominate the US market. FICO and Vantage are two major credit scoring methods in this credit market. Table 2 lists four samples of traditional credit management systems.

By cyber credit, we are referring to the one that is assessed with the data mainly obtained from the Internet-based new media, such as online market activities, social networking, instant messaging, Internet surfing, mobile communications, online banking, and so on. The cyber credit services are likely targeted at different agents in Internet finance.

Recently, many famous e-commerce companies develop their own big data based credit assessment system to mend the incapability of traditional credit reporting services. Examples include Alibaba's Sesame credit system, CreditEasy's Internet credit assessment system, Lending Club's 35-level credit system, and so on. Cyber credit is a multifaceted concept. Table 3 shows seven presently most popular cyber credit management systems (CCMS), which is an Internet-based information system with services of credit scoring, risk assessing, and real-time risk control, by analyzing massive data mainly collected from the Internet-based new media. CCMS is characterized by its revolutionary nature in the properties of real-time, big data based, social network correlated, and complexity.

We claim that cyber credit is whole-process, multi-dimensional, and holographic. A transaction process involves four stages: information collecting, negotiation, settlement, and after-sale (Gebauer \& Scharl 1999). Most of the existing studies only focus on analyzing individual's credit in the settlement phase, while the credit of a person/company is accumulated from and applicable to the whole process of e-commerce (Yuan et al. 2010; Wang et al. 2013; Olivero \& Lunt 2004; Posselt \& Gerstner 2005). The holographic nature of cyber credit is based on the fact that it relies on the analytics from big data and can provide services from all dimensions in different projections for diversified applications. This feature fits the needs of credit application for an individual playing four different roles in the market: buyers, sellers, borrowers, and lenders, which results in different credit scores in different business scenarios. Cyber credit is dynamic and volatile: On one hand, the scale of influencing factors of credit is changing in realtime because of far evolving e-commerce. On the other hand, the effect of these influencing factors on credit is dynamic in different contexts.

The features of cyber credit demanded by Internet finance have been far beyond the capability of traditional FICO system could handle-the single valued credit score has limited power in the e-commerce financial services. We suggest that cyber credit be represented in a vector with dimensions determined by the application scope. The following is a general description of cyber credit vector. 
Table 2 Traditional credit management systems

\begin{tabular}{|c|c|c|c|c|c|c|}
\hline Company & Products and services & Credit assessment model & Data source & Evaluation aspects & Service object & $\overline{\text { Founded }}$ \\
\hline Dun \& Bradstreet & $\begin{array}{l}\text { Finance solutions, operations } \\
\text { solutions, sales and marketing } \\
\text { solutions, Risk management } \\
\text { products }\end{array}$ & $\begin{array}{l}\text { RAM model, statistic analysis } \\
\text { model }\end{array}$ & $\begin{array}{l}\text { Company scale, company } \\
\text { history, lawsuit information, } \\
\text { finance information }\end{array}$ & $\begin{array}{l}\text { Company basic information, } \\
\text { finance information, operation } \\
\text { condition }\end{array}$ & medium-sized enterprise & 1841 \\
\hline Equifax & $\begin{array}{l}\text { Credit service, insurance } \\
\text { information service }\end{array}$ & $\begin{array}{l}\text { FICO model, Vantage credit } \\
\text { evaluation model }\end{array}$ & $\begin{array}{l}\text { Individual consumer credit } \\
\text { information }\end{array}$ & $\begin{array}{l}\text { Payment history, credit usage, } \\
\text { length of credit history credit } \\
\text { applications credit account }\end{array}$ & $\begin{array}{l}\text { Credit granting institutions, } \\
\text { Finance institution, company }\end{array}$ & 1899 \\
\hline TransUnion & $\begin{array}{l}\text { Credit report, information } \\
\text { management service, } \\
\text { industry risk analysis }\end{array}$ & $\begin{array}{l}\text { FICO model, Vantage credit } \\
\text { evaluation model }\end{array}$ & $\begin{array}{l}\text { Provide by } 7000 \text { data supply } \\
\text { institutions }\end{array}$ & $\begin{array}{l}\text { Payment history, credit usage, } \\
\text { length of credit history credit } \\
\text { applications credit account }\end{array}$ & $\begin{array}{l}\text { Credit granting institutions, } \\
\text { Finance institution, company }\end{array}$ & 1968 \\
\hline Experian & $\begin{array}{l}\text { Credit report, credit score, } \\
\text { credit monitoring, risk } \\
\text { decision support, } \\
\text { marketing, etc. }\end{array}$ & $\begin{array}{l}\text { FICO model, Vantage credit } \\
\text { evaluation model }\end{array}$ & $\begin{array}{l}\text { Credit granting institutions, } \\
\text { data agents, public } \\
\text { departments }\end{array}$ & $\begin{array}{l}\text { Payment history, credit usage, } \\
\text { length of credit history credit } \\
\text { applications credit account }\end{array}$ & $\begin{array}{l}\text { Credit granting institutions, } \\
\text { Finance institution, company, }\end{array}$ & 1996 \\
\hline
\end{tabular}


Table 3 Cyber credit management systems

\begin{tabular}{|c|c|c|c|c|c|c|}
\hline Company & Products and services & Credit assessment model & Data source & Evaluation aspects & Service object & Founded \\
\hline CreditEasy & $\begin{array}{l}\text { Credit report, lending } \\
\text { services, wealth } \\
\text { management }\end{array}$ & $\begin{array}{l}\text { Machine learning model, } \\
\text { GLM(LR) model, Random } \\
\text { forest model }\end{array}$ & $\begin{array}{l}\text { information provide by users, } \\
\text { internet information }\end{array}$ & unlimited & Individual consumers & 2006 \\
\hline OnDeck & Credit score, small loan & Big data analysis model & $\begin{array}{l}\text { Real-time information of } \\
\text { enterprise operation, bank } \\
\text { data, census data, tax data }\end{array}$ & $\begin{array}{l}\text { Cash flow, customer } \\
\text { reviews, etc }\end{array}$ & Small enterprises & 2006 \\
\hline Lending club & Peer-to-peer lending & Big data analysis model & Platform information & $\begin{array}{l}\text { Individual information, } \\
\text { loan information }\end{array}$ & $\begin{array}{l}\text { Individual lenders whose } \\
\text { Fico score over } 700\end{array}$ & 2006 \\
\hline Credit Karma & $\begin{array}{l}\text { Simple version of credit } \\
\text { report, credit score, credit } \\
\text { monitoring, finance } \\
\text { product recommendation }\end{array}$ & Statistic analysis model & $\begin{array}{l}\text { Traditional credit investigation } \\
\text { institutions }\end{array}$ & $\begin{array}{l}\text { Payment history, credit } \\
\text { usage, length of credit } \\
\text { history credit applications } \\
\text { credit account }\end{array}$ & Individual consumers & 2008 \\
\hline Zestfinance & Credit report, credit score & Ten big data analysis models & $\begin{array}{l}\text { Internet data, data provide } \\
\text { by users, third-party data }\end{array}$ & unlimited & $\begin{array}{l}\text { Individual lenders who } \\
\text { cannot get credit service } \\
\text { from traditional credit } \\
\text { institutions }\end{array}$ & 2009 \\
\hline WeCash & Credit report, credit score & Big data analysis models & $\begin{array}{l}\text { Information provide by users, } \\
\text { internet information }\end{array}$ & $\begin{array}{l}\text { Internet behavior, } \\
\text { individual credit history }\end{array}$ & Individual consumers & 2014 \\
\hline Sesame Credit & Credit report, credit score & $\begin{array}{l}\text { Linear regression, logistic } \\
\text { regression, decision tree, } \\
\text { neural network }\end{array}$ & $\begin{array}{l}\text { E-commerce data, e-finance } \\
\text { data, public departments, } \\
\text { information provide by users }\end{array}$ & $\begin{array}{l}\text { Credit history, interpersonal } \\
\text { connections, behavioral } \\
\text { preference, identity, } \\
\text { contractual capacity }\end{array}$ & Individual consumers & 2014 \\
\hline
\end{tabular}


- An individual's cyber credit is represented in a vector, $C$

- The number of elements, denoted as $n$, in the vector varies upon different needs

- In different contexts, there are different weight vectors, $w_{j}$

- The single value of cyber credit in an application scenario $j$ is $C \times w_{j}$

\section{A Big data oriented architecture for credit management}

Due to fast changing market environment in e-commerce environment, credit risk management is becoming more and more difficult, which is characterized as timeliness, huge amount of data, and small business size but large volume of demands. In this way, we propose a five-layer architecture of big data oriented credit management system. It consists of a pair of complementary subprojects, Big Data Based Credit Scoring for E-Commerce (BDCS) and Real-time Credit Risk Management (RCRM), as shown in Fig. 4.

\section{BDCS}

Big data based credit scoring (BDCS) is to evaluate customer credit using massive data analytics for e-businesses. To cope with the challenges of big data in e-commerce, special data relationship discovery techniques are to be applied to reveal seemingly irrelevant datasets or data attributes to extend the information about specific customers for the credit scoring purpose.

\section{RCRM}

Real-time credit risk management (RCRM) is to monitor and manage the evolving credit status of financial service customers in real-time, so that the credit risk can be properly handled whenever necessary. BDCS is applied prior to an e-financial service and RCRM is for posterior e-finance services. They have major differences from traditional off-line credit scoring and risk management, characterized by non-financial data, timeliness of responses, huge data volume, and complex inter-data relationship.

BDCS can be deployed alone for e-businesses before completion of RCRM. It will become the basis for the operation of RCRM, and its key technologies and models will also be the key components in RCRM. Nevertheless, there are still other major tasks to

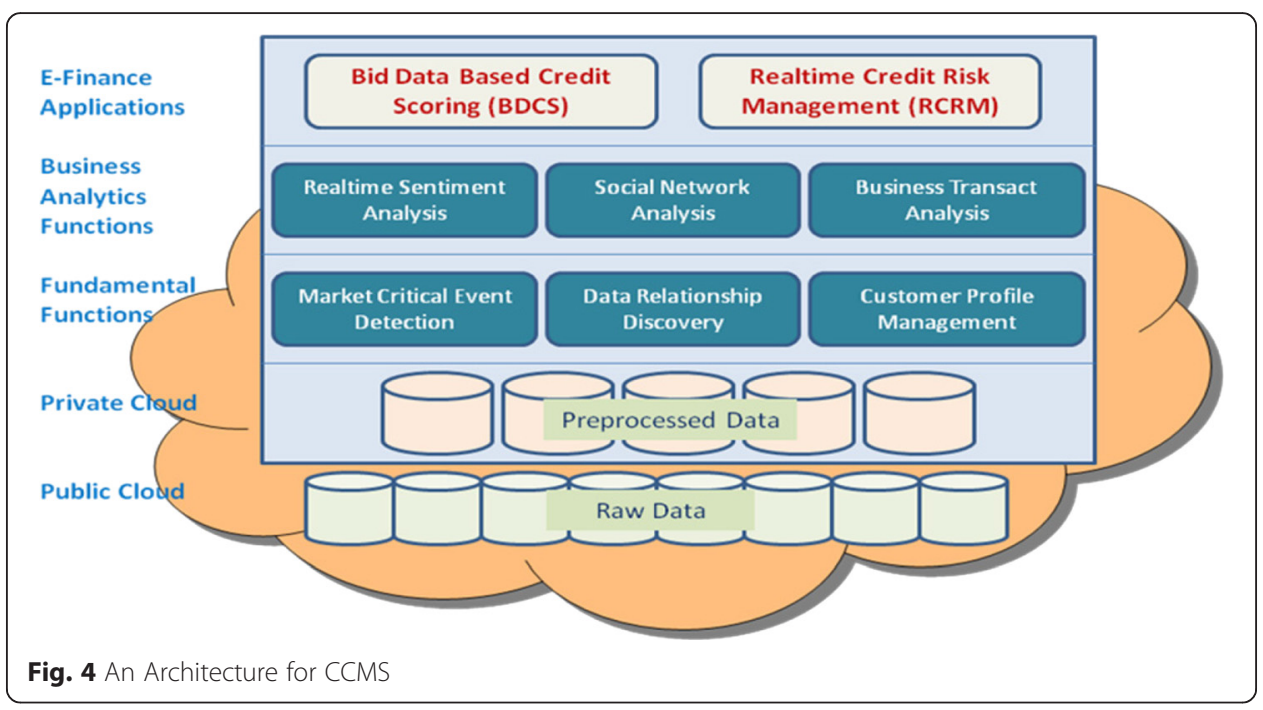


be done in RCRM. In this way, BDCR and RCRM can be conducted either simultaneously or sequentially, depending on available information resources and the risk aversion strategy.

\section{Research issues}

\section{Cyber credit governance}

By credit governance we mean the efforts and implementations in renovating the constitution of business credit system at both macro and micro levels by consolidating relevant legislation and regulation to effectively control the credit risks and avoid financial crises. In traditional finance industry, credit risk is defined as the risk of economic losses due to the counterparty fails to fulfill his or her contractual obligations (Voit 2003). Since the 2007 financial tsunami, many regulations around the world have been developed for credit risk management for banks. This is why Basel III (Basel 2012) was introduced in 2010 as an improvement of Basel II, for a stricter and better capital quality and risk coverage. However, in today's networked world empowered by ICT and big data technologies, finance innovations not only deliver unprecedented benefits to our society but also spread financial risk or crises faster and more severe since most of the current regulatory framework is not ready for Internet finance (Hu et al. 2012; Tan 2014). Therefore, we propose that the aim of cyber credit governance is to maintain a consistent and integrated cyber credit ecology to ensure the coherent operation of Internet finance, and reduce the credit risk to a controllable level.

\section{Constitution and regulations of cyber credit system}

Currently, government agencies such as Securities and Exchange Commission (SEC), at the US, or China Banking Regulatory Commission (CBRC), at China, are analyzing the cases of finance innovations and designing new regulation rules. As Internet finance is creating a more completive financial market, it may produce a far-reaching impact on credit risk management and demand the amendments to obsolete legal instruments (Luo 2013; Mishikin, F.S 2012; Tan 2014). For example, fostering Internet finance has the tendency to force China Central Bank to liberate the interest rate (Wei, L \& Mozur 2014). One issue that is particularly relevant to IS research is the role of platforms for various innovative finance services. Comparing with traditional finance industry, Internet finance relies on IT platforms to bridge customers and finance service providers. Therefore, the credit risk management for Internet finance should pay special attention to the platform. In 2008, the SEC of the US issued a Cease and Desist Order to Prosper. The SEC claimed that Prosper was selling securities, so Prosper should have registered as a public company with the SEC. Similarly, Lending Club encountered the same problem, as it set up Eaglewood Capital to invest in its loans. The problem is that if such P2P loan securitization is not regulated by credit risk control framework, the securitization of loans could be very risky. However, in another aspect, improper regulation may set hurdles to financial innovations (Verstein, A 2011). Thus, rules, policies, and laws should be developed or amended to govern cyber credit system in the way encouraging financial innovations while controlling risks at individual, company, and market levels. It seems that the issue of regulation or deregulation is still haunting the academia and industry since the case of AT\&T decomposition in 1980s (Economides 
1999). The challenge is how to conceive and renovate a right legal system for Internet finance in terms of different credit governance systems in different economies with different cultural backgrounds, and in different contexts.

\section{Cyber credit risk control}

Our society has experienced several financial crises or major financial risks in recent two decades. The forms of the crises are diversified-systematic ones such as Asia financial crisis in late 1990s, or financial tsunami during 2007-2008; burst ones, such as Dow Jones Industrial Index flash crash in 2010, or Everbright Securities' fat finger programmed trading in 2013; and localized crises, such as the P2P lending joint guarantee crash in 2014 at Sichuan and Zhejiang (Alois, JD, "Is China Going Through a Peer to Peer Lending Crisis?, "April 9 2015). As Internet finance is fast expanding, warnings about the crises caused by savage growth in this new territory are getting louder. Therefore, it is important to study the strategic-level risk control to prevent the crises in the early stage or to reduce the losses in every scattered financial risks.

How to analyze credit risk accurately is the core of credit risk management (Crouhy et al. 2000). According to the types of borrowers, credit risk can be basically divided into three categories: credit risk of large and medium-sized enterprises, credit risk of small and micro-sized enterprises, and individual credit risk. In an alternative angle, credit risk can be examined in accordance with its structure and sources. This is insightful because of the nature of cyber credit in the context of Internet finance.

The network level risk caused by the interrelationship among borrowers and lenders has caught attentions by both academia and industry (Hu et al. 2012; Rochet \& Tirole 1996). For example, a borrower can borrow money from different lenders and these lenders will have a relationship of sharing the same borrower. The relationship among borrowers could be built based on their social relationship such as colleagues, friends, etc. Such network level risk is especially important in Internet finance because social network effect plays a profound role in online environment, and central banks must be able to monitor and mitigate this kind of bank systemic risk (Hu et al. 2012).

Another type of risk source in internet finance is related to the platform. The reputation and business model of personal loan platforms are very important for investors. For example, it was found that many p2p platforms also have business models that obscure the relationship between borrowers and lenders and may pool investors' money. Apart from the problem of problematic business models, some platforms may even involve in "ponzi scheme" or fake p2p website. Table 4 provides a comparison of risk management between traditional system and Internet finance system. For Internet finance risks management, the key challenge is how to identify the most important data sources and build a valid risk management model based on the data.

\section{Theoretical research issues}

\section{The economics of internet finance}

The products and services of e-commerce have been extended from physical products to service products and further to credit-based financial service products. When ecommerce came in mid 1990s, it challenged the academia with a number of viable research topics in economics (Whinston et al. 1997): 
Table 4 Comparison Between Traditional and Internet Finance Risk Management

\begin{tabular}{|c|c|c|}
\hline Credit Risk Sources & Traditional Risk Management & Internet Finance Risk Management \\
\hline Personal Information & $\begin{array}{l}\text { Moral, personal, vocational, and } \\
\text { financial characteristics }\end{array}$ & $\begin{array}{l}\text { Personal Information in traditional } \\
\text { risk management, personal role in } \\
\text { finance market, personal behavior } \\
\text { on Internet such as online purchase, } \\
\text { online investment, social media } \\
\text { activities, project history }\end{array}$ \\
\hline Macroeconomic Information & $\begin{array}{l}\text { Employment rate, interest rate, } \\
\text { and stock change index }\end{array}$ & $\begin{array}{l}\text { Macroeconomic Information in } \\
\text { traditional risk management and } \\
\text { regulations on internet finance. }\end{array}$ \\
\hline Network Level Information & Not considered & $\begin{array}{l}\text { Lender-lender relationship, } \\
\text { lender-borrower relationship } \\
\text { Borrower-borrower relationship }\end{array}$ \\
\hline Platform Information & Not considered & $\begin{array}{l}\text { Platform information such as } \\
\text { guarantee, platform security, } \\
\text { policies, business model, and } \\
\text { reputation }\end{array}$ \\
\hline
\end{tabular}

- E-market mechanism

- Internet intermediaries

- Digital products and processes

- Product choice and pricing

- Quality uncertainty and market efficiency

- Copyright protection

- Consumer search

- Value of information

- Financial intermediaries

- Electronic payment

- Business and policy implications

Today, as e-commerce is roaring into the Internet finance era, it is surprising that the above are still active topics and the research outcomes from e-commerce area can be well applicable to Internet finance (Hu et al. 2004; Jie \& Chen 2015). The fundamental difference between e-commerce and Internet finance is in the objective: e-commerce is more focused on regular products but Internet finance is more focused on the pecuniary category of the products, which generates a wide range of virtual products stemmed in the credit. This explains why some recent advances in e-commerce were not mentioned before, for example, the economics of social capital (Putnam 1995; Glaeser et al. 2002).

Social capital is defined as "resources embedded in a social structure that are accessed and/or mobilized in purposive actions" (Lin et al. 2001). It is reported that an online consumer's social capital has the similar effect as the monetary capital in affecting his/her credit score (Liu et al. 2014; Li 2014; Li et al. 2015). Social capital theory suggests that economic behavior should not be analyzed without considering the constraints of ongoing social relations among individuals (Granovetter 1985). Social network ties have significant effects on crowd-funding performance in both China and the U.S (Lippert et al. 2014). The question becomes how to measure the value of social capital in accordance with its effect of monetary capital in the market. 


\section{Organizations and individuals in Internet finance}

In last 20 years, research on e-commerce has delivered proliferated theoretic outcomes in organizational and personal behaviors in terms of online trust, reputation, and perceived risk, by adopting the theories from sociology, psychology, statistics, economics, and so on. Extending exiting e-commerce research should be beneficial to the research effort in cyber credit related research, while the latter will open huge research opportunities to the former with e-commerce relevant topics, new constructs, diversified model and methods, and new theories.

Extending e-commerce research with new constructs in creditability There are several major constructs in the behavioral study of e-commerce. Online trust, measured by ability, benevolence, and integrity (Bhattacherjee 2002; Gefen 2000) is a central player in helping consumers overcome perceptions of risk, and facilitate their decision making process through leading to trust intention behaviors (Hoffman et al. 1999; Jarvenpaa et al. 2000; Ba \& Pavlou 2002). Consequently, a variety of trust building strategies, such as online seals program ( $\mathrm{Hu}$ et al. 2002), online escrow service (Hu et al. 2004), online endorsement (Kim \& Benbasat 2006; Lim et al. 2006), and online reputation systems (Resnick et al. 2000; Dellarocas 2003; Melnik \& Alm 2002) have been tested to affect trust and lead to the consequences of trust. The research from the angle of cyber credit should be able to provide new ingredients, such as decision theory (Simon 1979), analytic modeling, etc. to relevant IS research efforts with commonly used constructs. Further, the new constructs, such as creditworthiness, creditability, and credit risk, will bring in new research problems solvable with extended research models.

Applying IS research outcomes to cyber credit research Prior IS research outcomes actually refuel current cyber credit research in more than one way (Li et al. 2011; Safi \& Lin 2014). For example, in online P2P lending credit risk research, borrower's social capital/social networks on loan performance has been well discussed following the methodologies used in IS research (Liu et al. 2014; Berger \& Gleisner 2009; Greiner, M. E \& Wang 2009; Greiner \& Wang 2010; Everett, C. R 2010; Lin et al. 2013; Xia et al. 2012). In particular, the approach of cultural comparison has been applied in the credit risk research. For example, cultural influence in social capital, which is widely used in classical IS research, has been introduced to P2P lending market research (Li 2014; Xu et al. 2010; Qiu et al. 2011; Chen \& Han 2012). Nevertheless, the possible research topics in cyber credit management underpinned by the research outcomes from the IS area may cover a broad range:

- The incentive mechanisms for assured credibility

- Reputation, perceived risk, and trust vs. creditworthiness

- How cyber credit affects the e-commerce and online financing

- The relationship between trade credit and bank credit in the e-commerce context

- How social capital contributes to cyber credit

- Friendship networks and credibility of online lending

- Effects of cyber credit in different stages of e-commerce 


\section{Technological challenges}

Traditional credit assessment applies analytic models to evaluate a person's credit score in a numerical expression based on a level analysis of the person's credit documents, to illustrate the creditworthiness of that person (Liao et al. 2009; Lindset et al. 2014), including time series modeling (Creal et al. 2014), SOM/K means clustering (Farming 2012), multi-agent modeling (Jiang et al. 2015), and so on. Now this kind of methodologies is challenged by the nature of big data in four Vs-volume, value, variety, and velocity (Zhao et al. 2014; Fan et al. 2015).

\section{Big data based cyber credit assessment}

There are various existing methods in assessing a customer's credit score. For example, FICO score, known as Fair Isaac Corporation, is used by many mortgage lenders to determine the possibility that the borrower may default on financial obligations to the mortgage lender. These credit scoring approaches are characterized by financial information based, computational intensified, and latency-tolerant offline data analysis. Today, a cyber credit system is confronted by a broad range of data, and majority of these data are unstructured: social networking information, such as social network structure and interaction messages; e-market transactions, such as bidding information; business reports and essays; and reputation rating and review comments (Pavlou \& Dimoka 2006).

Current methodologies in cyber credit research have gone beyond previously pure technical methods with various ingredients:

- Social capital becomes the ability of actors to secure benefits by virtue of membership in social networks or other social structures (Portes, A 2000).

- Social network structure can reflect the position of actors in a network. The indicators of social network structure include degree centrality, betweenness centrality, closeness, and so on (Hanneman \& Riddle 2005; Cao 2013).

- The relevant information for credit risk analysis is more than finance information (or "hard information"), but includes "soft information", for example, reputation and social network information (Iyer et al. 2009).

The findings from the above efforts are encouraging:

- In the case of B2B credit assessment, the influencing factors of firms' credit in B2B transaction include the history of the firm in B2B exchange, the level of firm activity, the intensity of interaction with partners and geographical diversification of customers (Safi \& Lin 2014).

- Friendship relationships may act as pipes, primes, and rational herding signals in a large P2P lending site (Liu et al. 2014; Li 2014).

The above research outcomes imply that cyber credit may provide a good bridge between monetary capital and social capital, and makes them transferrable regarding bank credit, consumer credit, and trade credit. This then paves the way to apply cloud computing, parallelized data analysis algorithm, and heuristic search in tackling practical cyber credit assessment problems as follows: 
- Data selection-to narrow down to the most informative and relevant data sources.

- Noise filtering-to remove irrelevant information and hence reduce information overload problem.

- Data correlation analysis-to discover the hidden relationships between different data items and datasets.

- Data confliction discovery. An important topic in Information fuse is to resolve conflicts from different sources and finding the truth that reflects the real world.

\section{Real-time credit risk control techniques}

To cope with rapid changing electronic market cyber risk control demands advanced techniques that can dynamically detect the change of credit level of a person or a company, which are timely and spatially effective enough.

The algorithm for efficient analysis of social networks in real-time Since social network data contributes significantly to cyber credit assessment, its computational efficiency is critically important (Li 2014; Cao 2013). Extracting meaningful features from social networks is usually very computationally expensive. As an answer to the problems of big data analysis, the development is directed towards parallel processes (Oliver 1990). Although Hadoop has been developed for big data processing, accompanying with the general computational algorithm MapReduce (http://www-01.ibm.com/software/data/infosphere/hadoop/mapreduce/), its earlier version is not powerful enough for online transactional processing (OLTP) application because of latency. Since 2014, Spark was adopted by industry to replace Storm (http://hortonworks.com/ hadoop/storm/) in Hadoop 2.0 for streaming data processing. $\mathrm{H} 2 \mathrm{O}$ is now taking over the position of Mahout (https://mahout.apache.org/) in data mining tasks, and graph database, such as Neo4J (http://neo4j.org/), is getting momentum. Even though, these parallel computing architectures are still challenged by the complexity of credit computational tasks, mainly in social network computing. Therefore, exploration for more powerful parallel algorithms in the environment of Hadoop is a must.

The advanced analytics using big data to improve financial inclusion Big data's financial empowerment potential can be unleashed through wider adoption of more inclusive credit scores. VantageScore (O'Connor 2014), for example, utilizes advanced analytics and reaches deeper into the credit file by integrating new data points, like rental payments, to help score consumers who previously were unscoreable. The impact of these analytics equates to bringing into the financial mainstream between 30 million and 35 million creditworthy consumers who previously would have been unscoreable using legacy credit scoring models. This is just one example of how advanced analytics using big data derived from credit databases can help achieve the goal of greater financial inclusion. ZestFinance (Crossman 2012) is a startup that uses machine learning and large-scale big data analysis to help companies make more accurate financial decisions. They provide credit information for borrowers, particularly for millions of underbanked Americans, and higher repayment rates for lenders. Thus, how to use big data analytics that combine large amount of data from various data resources to quantify credit information is a challenge that needs to be addressed. 


\section{Concluding remarks}

Enabled by big data and ICT, Internet finance opens up a new exciting means of financing. The impact of Internet finance is multifaceted and profound. It allows financial institutions to extend their traditional business model to online platforms and directly interact with their customers on the Internet with few intermediaries. In this paper, we investigated the current status of Internet finance and summarized five aspects of finance innovation that are enabled by Internet and big data technologies. Based on the analysis of all five finance innovations, we proposed a market structure of Internet finance that is extended from traditional financial market. We further raised the issue of online credit management system for Internet credit and propose an architecture of big data based credit risk management system, which incorporates all sorts of information on Internet accessible. Credit risk in Internet finance can be analyzed by using the data of personal information, network information, macroeconomic information and platform information.

This paper also proposed some of the new theoretical, technical and managerial research opportunities that arise from Internet finance. We believe this is an opportunity for IS research to take a leadership effort in interpreting and guiding this trend into fully realizing its potential. From the theoretical perspective, we need to study the nature of credit in Internet finance and untangle the relationship between credit in Internet finance and e-commerce and the relationship between monetary capital and social capital. From the technical perspective, algorithms that can handle big data from different resources in a real time manner will be required by the credit management system. Lastly, from the governance perspective, mechanisms of credit risk control and regulations should also be investigated for Internet finance. These research issues may expand theoretical basis of IS and other related fields by exploring how fundamentally new things may be observed in Internet finance.

Competing interests

The authors declare that they have no competing interests.

\section{Authors' contributions}

ZL: Developed concepts, conceived framework, and wrote majority of the paper. SF : Wrote some key sections, and contributed in some concepts of the paper. ABW : Discussed the major ideas and concepts in this paper, and analysis the relationship between current big data based financial innovations and the e-commerce framework he researched in mid 1990s. All authors read and approved the final manuscript.

\section{Acknowledgement}

The authors thank for the contributions to this research by Kun Liang, Xianfeng Zhang, Jiangtao Qiu, Meiqi Pan, Simling Li, and Jun Tan in reference summarizations, case studies, data processing, and discussions.

\section{Author details}

${ }^{1}$ The Rawls College of Business Administration, Texas Tech University, 703 Flint Avenue, Lubbock, TX 79409-2101, USA. ${ }^{2}$ Southwestern University of Finance and Economics, Chengdu, Sichuan, China. ${ }^{3}$ The University of Texas at Austin, Austin, Austin TX78712, USA. ${ }^{4}$ West Texas A \& M University, Canyon, TX 79016, USA.

Received: 7 May 2015 Accepted: 12 May 2015

Published online: 09 June 2015

References

Akerlof GA (1970) The market for 'lemons': Quality uncertainty and the market mechanism. The quarterly journal of economics, 84(3):488-500

Alois JD (2015) Is China Going Through a Peer to Peer Lending Crisis?, http://www.crowdfundinsider.com/2015/04/ 65829-is-china-going-through-a-peer-to-peer-lending-crisis/

Ba S, Pavlou PA (2002) Evidence of the effect of trust building technology in electronic markets: Price premiums and buyer behavior. MIS Quarterly, 26(3):243-268

Basel Committee on Banking Supervision, "Basel III counterparty credit risk and exposures to central counterparties Frequently asked questions," December 2012, http://www.bis.org/publ/bcbs237.pdf 
Berger SC, Gleisner F (2009) Emergence of financial intermediaries in electronic markets: The case of online P2P lending. BuR-Business Res 2(1):39-65

Bhattacherjee A (2002) Individual trust in online firms: Scale development and initial test. J Manag Info Systems 19(1):211-241

Brezo F, GBringas P (2012) Issues and risks associated with cryptocurrencies such as Bitcoin. In: SOTICS 2012, The Second International Conference on Social Eco-Informatics., pp 20-26

Cai K (2013) The actual financing cost is only 6.7 \%: Ali finance shocks the private lending., http://business.sohu.com/ 20130320/n369488586.shtml

Cao XB (2013) Measurement and the role of social capital in online P2P lending market," PhD Dissertation, June, 2014

Cecilia (2015) Yu'E Bao Exceeded 578.9 BIn Yuan in 2014., http://www.chinainternetwatch.com/11837/yue-baos-2014/

Chang X, Deng S (2014) The development of supply chain finance in China. Int J Manag Excellence 3(3):475-479

Chen D, Han C (2012) A Comparative Study of online P2P Lending in the USA and China. J Internet Banking Commerce 17(2):1-15

Chen D, Lai F, Lin Z (2014) A trust model for online peer-to-peer lending: A lender's perspective," Information Technology and Management., pp 1-16

Creal D, Schwaab B, Koopman SJ, Lucas A (2014) Observation-Driven Mixed-Measurement Dynamic Factor Models with an Application to Credit Risk. Rev Economics Statistics 96(5):898-915

Crossman P (2012) ZestFinance Aims to Fix Underwriting for the Underbanked., American Banker

Crouhy M, Galai D, Mark R (2000) A comparative analysis of current credit risk models. J Banking Finance 24(1):59-117

Dellarocas C (2003) The digitization of word of mouth: Promise and challenges of online feedback mechanisms. Manag Science 49(10):1407-1424

Deloitte (2014) Ten big trend and prospect of China banking in 2014., http://www2.deloitte.com/content/dam/ Deloitte/cn/Documents/financial-services/deloitte-cn-fs-2014top10trends-zh-2508143.pdf

Ding AW, Li S, Chatterjee P (2015) Learning User Real-Time Intent for Optimal Dynamic Web Page Transformation, Information Systems Research, Published online in Articles in Advance, 01 Apr 2015

Diniz E, Birochi R, Pozzebon M (2012) Triggers and barriers to financial inclusion: The use of ICT-based branchless banking in an Amazon county. Electron Commerce Res App 11(5):484-494

Dong H, Zhang X, Dong Y, Chen C, Rao F (2008) (2014, October). "Recommend a profitable cruising route for taxi drivers., In Intelligent Transportation Systems (ITSC), 2014 IEEE 17th International Conference, 2003-2008

Duncan H (2015) Chinese E-Commerce Grew 31 \% To More Than Trillion Last Year, Further Growth Predicted., http:// www.ibtimes.com/chinese-e-commerce-grew-31-more-2-trillion-last-year-further-growth-predicted-1873697

Economides N (1999) The Telecommunications Act of 1996 and its impact. Japan World Economy 11(4):455-483

Everett, CR (2010) Group membership, relationship banking and loan default risk: the case of online social lending. SSRN Working paper, Last revised: October 5, 2014, http://papers.ssrn.com/sol3/papers.cfm?abstract_id=1114428

Farming Z (2012) A New Method of Dynamic Credit Evaluation based on SOM-K and Its Application. JDCTA 6(13):378-387

Fan S, Lau R, Zhao JL (2015) Demystifying Big Data Analytics for Business Intelligence through the Lens of Marketing Mix. Big Data Res 2(1):28-32

Gebauer J, Scharl A (1999) Between flexibility and automation: an evaluation of web technology from a business process perspective. J Computer-Mediated Commun 5(2):1-25

Gefen D (2000) E-commerce: the role of familiarity and trust. Omega 28(6):725-737

Glaeser EL, Laibson D, Sacerdote B (2002) An Economics Approach to Social Capital. Economic J 112(November):F437-F458

Glossbrenner A, Glossbrenner E (1994) Making money on the Internet., Windcrest, 306p.

Granovetter M (1985) Economic action and social structure: the problem of embeddedness. American journal of sociology, 91(3):481-510

Greiner ME, Wang H (2009) The role of social capital in people-to-people lending marketplaces., pp 1-17. doi:1, ICIS 2009 Proceedings

Greiner ME, Wang H (2010) Building consumer-to-consumer trust in e-finance marketplaces: An empirical analysis. Int J Electron Commerce 15(2):105-136

Hanneman RA, Riddle M (2005) Introduction to social network methods. University of California, Riverside, CA

Harrison R (2013) Crowdfunding and the revitalisation of the early stage risk capital market: catalyst or chimera? Venture Capital 15(4):283-287

Hoffman DL, Novak TP, Peralta M (1999) Building consumer trust online. Communications ACM 42(4):80-85

Hu X, Lin Z, Zhang H (2002) Trust promoting seals in electronic markets: an exploratory study of their effectiveness for online sales promotion. J Promot Manag 9(1-2):163-180

Hu X, Lin Z, Whinston AB, Zhang H (2004) Hope or hype: On the viability of escrow services as trusted third parties in online auction environments. Info Systems Res 15(3):236-249

Hu D, Zhao JL, Hua Z, Wong MC (2012) Network-based modeling and analysis of systemic risk in banking systems. MIS Quarterly 36(4):1269-1291

Iyer R, Khwaja Al, Luttmer EF, Shue K (2009) Screening peers softly: Inferring the quality of small borrowers Working paper Jarvenpaa SL, Tractinsky N, Vitale M (2000) Consumer Trust in and Internet Store. Info Tech Manag 1(1-2):45-71

Jiang W, Xu Y, Guo H, Zhang L (2015) Multi Agent System-Based Dynamic Trust Calculation Model and Credit Management Mechanism of Online Trading. In: Qiaohong Zu, Bo Hu, Ning Gu, Sopheap Seng (eds) Human Centered Computing, Springer International Publishing, 168-181

Jie S, Chen H (2015) Internet Finance Innovation and Traditional Bank Transformation Based on Big Data." Finance \& Economics, 1, 002

Johnson E (2014) Alibaba Sparks a Revolution in Asset Management in China., http://www.institutionalinvestor.com/article/ 3390213/research-and-rankings/alibaba-sparks-a-revolution-in-asset-management-in-china.html\#.VSH4yvTMpyk

Kauffman RJ, Riggins FJ (2012) Information and communication technology and the sustainability of microfinance. Electron Commerce Res Appl 11(5):450-468

Kim D, Benbasat I (2006) The effects of trust-assuring arguments on consumer trust in Internet stores: Application of Toulmin's model of argumentation. Info Systems Res 17(3):286-300 
Kuppuswamy V, Bayus BL (2013) Crowdfunding Creative Ideas: the Dynamics of Projects Backers in Kickstarter Working Paper Li SM (2014) Social Capital Based Credit Evaluation for P2P Lending Market PhD Dissertation

Li X (2015) Ant Financial Subsidiary Starts Offering Individual Credit Scores., http://english.caixin.com/2015-03-02/ 100787148.html

Li S, Qiu J, Lin Z, Qiu J (2011) Do borrowers make homogeneous decisions in online P2P lending market? an empirical study of PPDai in China. In: Service Systems and Service Management (ICSSSM), 2011 8th International Conference., pp 1-6

Li SM, Lin Z, Qiu J, Safi R, Xiao Z (2015) How friendship networks work in online P2P lending markets. Nankai Business Rev Int 6(1):42-67

Liao HH, Chen TK, Lu CW (2009) Bank credit risk and structural credit models: Agency and information asymmetry perspectives. J Banking Finance 33(8):1520-1530

Lim KH, Sia CL, Lee MK, Benbasat I (2006) Do I trust you online, and if so, will I buy? An empirical study of two trust-building strategies. J Manag Info Systems 23(2):233-266

Lin N, Fu YC, Hsung RM (2001) The position generator: Measurement techniques for investigations of social capital." Social capital: theory and research. Aldine de Gruyter, New York, pp 57-81

Lin M, Prabhala NR, Viswanathan S (2013) Judging borrowers by the company they keep: friendship networks and information asymmetry in online peer-to-peer lending. Manag Science 59(1):17-35

Lindset S, Lund AC, Persson SA (2014) Credit risk and asymmetric information: A simplified approach. J Economic Dynamics Control 39:98-112

Lippert J (2014) ZestFinance issues small, high-rate loans, uses big data to weed out deadbeats, http:/www.washingtonpost.com/business/zestfinance-issues-small-high-rate-loans-uses-big-data-to-weed-out-deadbeats/ 2014/10/10/e34986b6-4d71-11e4-aa5e-7153e466a02d_story.html, October 11, 2014

Liu D, Brass D, Chen D (2014) Friendships in Online Peer-to-Peer Lending: Pipes, Prisms, and Relational Herding., pp 1-35

Luo B (2013) A Study on the Key Issues in Social Network Based Online Investing and Financing Services." PhD Dissertation

Mao AY, Song YY, Yu JX (2015) The Realization of the O2O Model in Mobile E-Commerce Based on the Technology of the Wechat Platform. In App Mechanics Materials 743:641-645

Marte J (2011) Beyond the Money Market., http://www.wsj.com/articles/SB10001424052702303763404576418172992611898

Melnik MI, Alm J (2002) Does a seller's ecommerce reputation matter? Evidence from eBay auctions. J Industrial Economics 50(3):337-349

Mishikin FS (2012) Economics of Money, Banking, and Financial Markets, 10th edition, Prentice Hall

Mishkin FS (2012) Central banking after the crisis. In: Central Bank of Chile, Monetary Policy and Financial Stability, Sixteenth 16 th Annual Conference of the Central Bank of Chile., pp 1-45

Niranjanamurthy M, Kavyashree N (2013) Analysis of E-Commerce and M-Commerce: Advantages, Limitations and Security issues. Int J Advanced Res Computer Commu Engr 2(6):2360-2370

O'Connor D (2014) From FICO to VantageScore and Beyond: What Does the Future Hold for the Best Scoring Model as Applied to People with Thin Credit Files?: an Honors Thesis" (Doctoral dissertation, lona College)

Oliver A (1990) McBryan, Trends in Parallel Computing. DTIC Online

Olivero N, Lunt P (2004) Privacy versus willingness to disclose in e-commerce exchanges: The effect of risk awareness on the relative role of trust and control. J Economic Psychology 25(2):243-262

Ordanini A, Miceli L, Pizzetti M, Parasuraman A (2011) Crowd-funding: transforming customers into investors through innovative service platforms. J Service Manag 22(4):443-470

Pavlou PA, Dimoka A (2006) The nature and role of feedback text comments in online marketplaces: Implications for trust building, price premiums, and seller differentiation. Info Systems Res 17(4):392-414

Portes A (2000) Social capital: Its origins and applications in modern sociology. in lesser, Eric L. (eds) Knowledge and Social Capital. Butterworth-Heinemann, Boston, pp 43-67

Posselt T, Gerstner E (2005) Pre-sale vs. Post-sale e-satisfaction: Impact on repurchase intention and overall satisfaction. J Interactive Marketing 19(4):35-47

Prive T (2012) What is Crowdfunding And How Does It Benefit The Economy., Retrieved December, 4, 2012

Putnam RD (1995) Tuning in, tuning out: The strange disappearance of social capital in America. Political Sci Politics 28(04):664-683

Qiu J (2013) A Theoretical Study on Costs-Benefits of Payment Instrument from the Perspective of Financial Structure," PhD Dissertation

Qiu J, Xu Y, Chen D, Lin Z (2011) The Effects of Social Capital in Chinese Online P2P Lending Market. Energy Procedia 13:9866-9874

Resnick P, Kuwabara K, Zeckhauser R, Friedman E (2000) Reputation systems. Commun ACM 43(12):45-48

Rochet JC, Tirole J (1996) Interbank lending and systemic risk. Journal of Money, credit and Banking, 1996:733-762 http://www.dnb.nl/binaries/sr047 tcm46-146825.pdf.

Safi R, Lin Z (2014) USING NON-FINANCIAL DATA TO ASSESS THE CREDITWORTHINESS OF BUSINESSES IN ONLINE TRADE. Pacific Asia Conference Info Systems 2014:1-12

Shao H (2013) In China, 'Cats And Dogs Are All Opening Banks., http://www.forbes.com/sites/hengshao/2013/09/27/892/

Simon HA (1979) "Rational decision making in business organizations." The American economic review, 493-513

Sina Finance (2015) Broaden and Deepen Cooperation among Pan-Finance Firms", April 3, 2015., http://finance.sina.com.cn/ money/future/fmnews/20150403/094221881953.shtml

Somervill H (2014) Lending Club nabs $\$ 9$ billion valuation in IPO, challenges big banks., http://www.mercurynews.com/ business/ci_27116087/lending-club-jumps-65-percent-silicon-valleys-biggest

Tan J (2014) "A Study on Regulatory Strategy of P2P Lending Market for Building Industry Self-regulatory Mechanism," PhD Dissertation, June, 2014

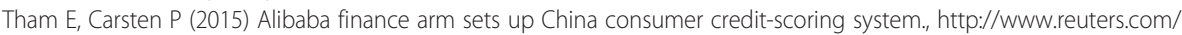
article/2015/01/28/us-alibaba-group-credit-ratings-idUSKBNOL10LF20150128, Jan 28, 2015

Tong F (2015) China's dominant payment network prepares to battle Alibaba., https://www.internetretailer.com/2015/ 01/09/chinas-dominant-payment-network-prepares-battle-alibaba" 
Verstein A (2011) The Misregulation of Person-to-Person Lending., November 21, 2011, SSRN, http://papers.ssrn.com/ sol3/papers.cfm?abstract_id=1823763

Voit J (2003) The statistical mechanics of financial markets (Vol. 2). Springer, Berlin

Wagner A (2014) Digital vs. Virtual Currencies., https://bitcoinmagazine.com/15862/digital-vs-virtual-currencies/, August 22, 2014

Wang J, Yuan S (2015) Real-time bidding: A new frontier of computational advertising research. In: Proceedings of the Eighth ACM International Conference on Web Search and Data Mining., pp 415-4161

Wang Y, Li S, Lin Z (2013) Revealing Key Non-financial Factors for Online Credit-Scoring in e-Financing. In: 2013 10th International Conference on Service Systems and Service Management (ICSSSM)., pp 547-552

Wei L, Mozur P (2014) "China's Central Bank Leads Effort to Regulate Internet Finance., Wall Street Journal, February, 11, 2014, http://www.wsj.com/articles/SB10001424052702303874504579376111028523376

Whinston AB, Stahl DO, Choi SY (1997) The Economics of Electronic Commerce., MacMillan Publishing Company Wu S, Wang B, Li Y (2015) How to attract the crowd in crowdfunding? Int J Entrep Small Business 24(3):322-334

Xia M, Huang Y, Duan W, Whinston AB (2012) Research Note-To Continue Sharing or Not to Continue Sharing? An Empirical Analysis of User Decision in Peer-to-Peer Sharing Networks. Information Systems Research 23(1):247-259

Xinhua (2014) Alibaba chairman's financing firm granted to set up private bank, 2014., http://europe.chinadaily.com.cn/ business/2014-09/29/content_18682842.htm

Xu Y, Qiu J, Chen D (2010) Profit vs. Non-Profit Business Based on P2P Lending: A Cross-Country Multiple Case Study, in The Tenth International Conference on Electronic Business., pp 218-224

Yuan D, Lu T, Yang X, Yan L (2010) A theory analysis and model research on e-commerce credit risk management. In: 2010 International Conference on E-Business and E-Government (ICEE)., pp 2006-2009

Zhao JL, Fan S, Hu D (2014) Business Challenges and Research Directions of Management Analytics in the Big Data Era. J Management Analytics 1(3):169-174

\section{Submit your manuscript to a SpringerOpen ${ }^{\circ}$ journal and benefit from:}

- Convenient online submission

- Rigorous peer review

- Immediate publication on acceptance

- Open access: articles freely available online

- High visibility within the field

- Retaining the copyright to your article 